\title{
The nutritive value of veld as indicated by faecal phosphorous and nitrogen and its relation to the condition and movement of prominent ruminants during the 1992-1993 drought in the Kruger National Park
}

\author{
C.C. GRANT, H.H.MEISSNER and W A SCHULTHEISS
}

\begin{abstract}
Grant C. C., H.H. Meissner and W.A. Schultheiss. 1995. The nutritive value of veld as indicated by faecal phosphorus and nitrogen and its relation to the condition and movement of prominent ruminants during the 1992-1993 drought in the Kruger National Park. Koedoe 38(1): 17-31. Pretoria. ISSN 0075-6458.

Faecal $\mathrm{N}$ and $\mathrm{P}$ were used as primary indicators of nutritive quality of the veld in relation to migratory movements of major grazers, browsers and selective feeders. Faecal concentrations of these nutrients were shown to be different between species, landscapes, grass, browse and grass plus browse, between seasons and between soil types. i.e. granite vs. basalt. Faecal $\mathrm{N}$ concentrations were well correlated with the condition of the animals, and because nutritive quality of the southern Combretum veld on granite was apparently better than other areas in 1992-1993. also with influx of buffalo. blue wildebeest and kudu into these areas.
\end{abstract}

Key words: Faecal analysis, nitrogen, phosphorus, veld quality, granite, basalt, ruminants.

C.C.Grant. Kruger National Park, Box I06, Skukuza, 1350 Republic of South Africa, H. H. Meissner, Department of Animal and Wildlife Sciences, University of Pretoria, Pretoria, 0002 Republic of South Africa: W.A. Schultheiss, Department of Veterinary Etholog: University of Pretoria. Onderstepoort. O110 Republic of South Africa.

\section{Introduction}

A drought is expected to result in a decline in both the quality and quantity of fodder available to herbivores. This would result in a loss of condition, mortalities and or failure to reproduce, the magnitude of which will depend on the severity and duration of the drought. The drought of 1992-1993 in the Kruger National Park (KNP) was particularly devastating, resulting in a severe decline in the buffalo population from 29300 to 15400 (Whyte \& Wood 1994). Whereas the decrease in available forage is visible. the slower preceding deterioration in quality that erodes the reserves of the animal is less noticeable. It would be of value to monitor the decline in forage quality to facilitate timely decisions.
Faecal nitrogen $(\mathrm{N})$ and phosphorus (P) offer a solution because they are correlated to $\mathrm{N}$ and $\mathrm{P}$ in the fodder consumed by the animal (Moir 1960, 1966: Belonje 1980; Wadsworth et al. 1990; Grant 1989). Nitrogen concentration in the faeces also reflects forage digestibility (Lancaster 1949; Moir 1960; Holecheck et al. 1982). These correlations are, furthermore, improved if $\mathrm{N}$ and $P$ concentrations in the faeces are considered together because their excretion is linked (Moir 1966; Grant 1989), and if the season and locality, i. e. landscape are also defined (Grant 1989).

The purpose of this investigation was therefore: to evaluate faecal $\mathrm{N}$ and $\mathrm{P}$ as a routine measure to monitor changes in veld quality; to define landscapes in terms of 


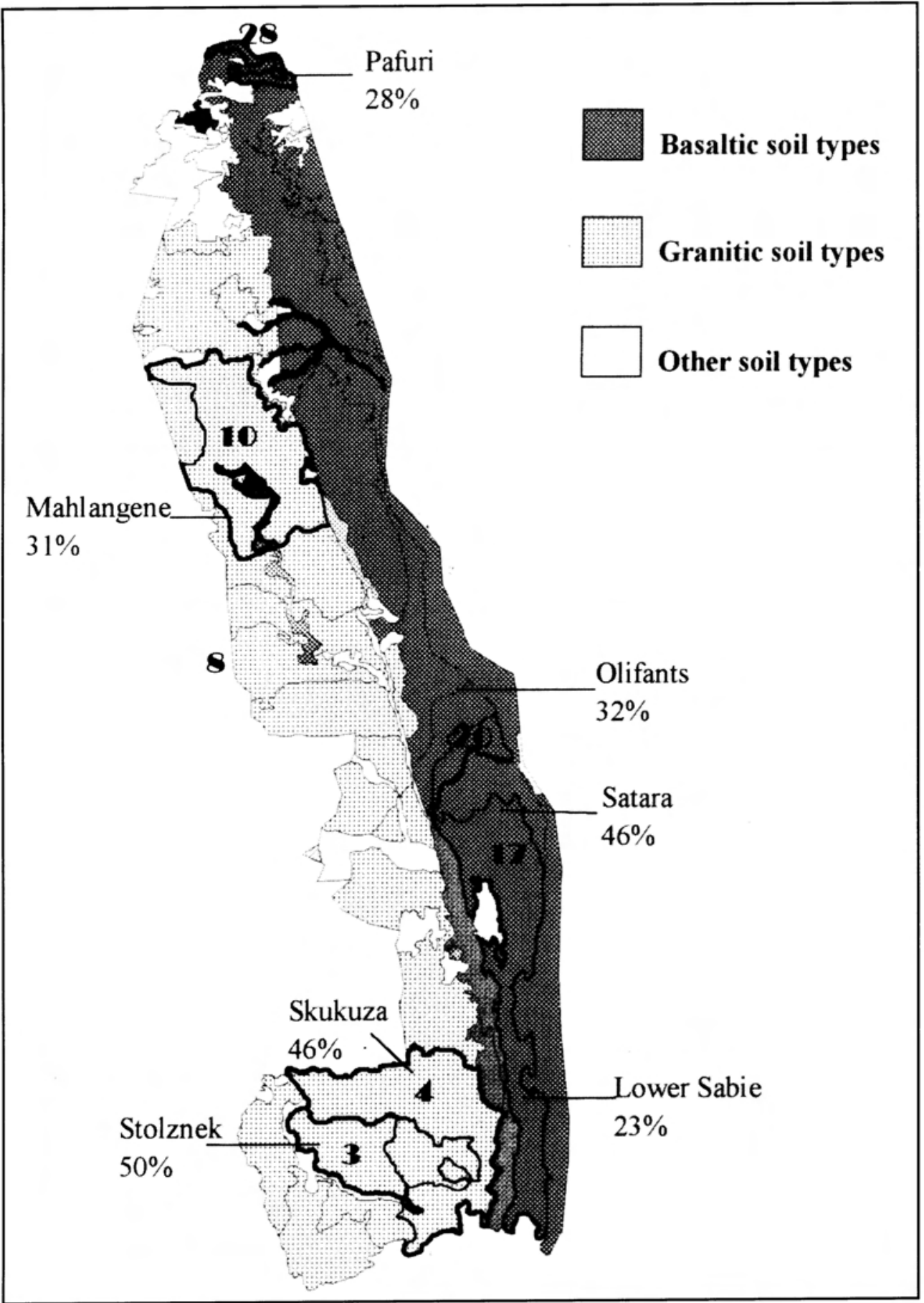

Fig. 1. Landscapes of the Kruger National Park from which faecal samples were collected and the precipitation as a percentage of the long term rainfall. 
fodder quality; and to explain alterations in condition and migratory movements of major grazing and browsing ruminants in the drought years of 1992-1993.

\section{Methods}

\section{Study area}

Faecal samples were collected from a selection of landscapes representative of the major plant and soil types in the park. These are illustrated in Fig. 1 and are described by Gertenbach (1983) as:

Landscape

3 Combretum collinum/C zeyheri Woodland

4 Thickets of the Sabie and Crocodile Rivers

5 Mixed Combretum spp. I Terminalia sericea Woodland

8 Phalaborwa Sandveld

10 Letaba River Rugged Veld

17 Sclerocarya caffira/Acacia nigrescens Savanna

20 Bangu Rugged Veld

28 Limpopo/Luvuvhu Floodplains

Landscapes 3-10 have granitic soil, 17 and 20 basaltic soils, and 28 alluvial soils. Rainfall during 1992-1993 was well below the long-term average in all the landscapes as illustrated (Fig. I)

\section{Sample collection}

Fresh, clean, faecal samples were collected at approximately monthly intervals from May 1992 to May 1993 from all landscapes. Two grazer species, buffalo (Syncerus caffer) and blue wildebeest (Connochaetes taurinus), a mixed feeder, the impala (Aepyceros melampus) and two browser species, the kudu (Tragelaphus strepsiceros) and giraffe (Giraffa camelopardalis), were included in the study to represent all feeding strata. To obtain a representative sample, 20 dung heaps were sampled per landscape per month for buffalo and blue wildebeest, and pooled for analyses. Impala samples were also collected from 20 dung heaps, but care was taken to avoid the dung from young animals. These samples were also pooled per landscape and per month before analysis. For browsers it was difficult to collect large numbers of samples. Samples of kudu and giraffe were, therefore, obtained from at least 5 dung heaps and analysed individually.
All samples were less than one day old. These were collected in thin P,Acr bags, and the date of collection, number of samples and a general description of the grazing available, was noted.

\section{Processing and analysis of samples}

Samples were stored in a cool dry place to avoid fungal growth and transported to the Skukuza laboratory as soon as feasible. On arrival, they were immediately oven-dried at $65^{\circ} \mathrm{C}$ to constant weight, and then ground using a mortar and pestle. For $\mathrm{P}$ analyses samples were sieved through a $150 \mu \mathrm{m}$ sieve to remove all undigested residue. The sieved material was then ashed in a muffle furnace and the ash dissolved in diluted $\mathrm{HCl}$. Phosphorus concentration was determined spectrophotometrically according to AOAC (1984). Nitrogen concentration was determined on the unsieved sample, using the standard Kjeldahl technique (AOAC 1975). Both analyses were performed at the Department of Veterinary Ethology at Onderstepoort.

\section{Condition scoring}

The condition of the animals was scored using an arbitrary scale of 1 to 5 , where I represents very poor and 5 fat. Animals in good condition fell in classes 3 and 4 , whereas their reserves start deteriorating below a score of about 2.5 .

\section{Census}

Species numbers were obtained from the annual census reports issued by the Scientific Services Section at Skukuza (Viljoen et al. 1993). The census results were regrouped to coincide approximately with the boundaries of the landscapes on granitic and basaltic soils.

\section{Statistical analyses}

The data were analysed using multi-factor analysis of variance. Variables were species, season and landscape, and type of grazing on granite vs. basalt soil types for different seasons. Nitrogen and P concentrations in faeces were also related in regression analysis and where applicable, correlated to 

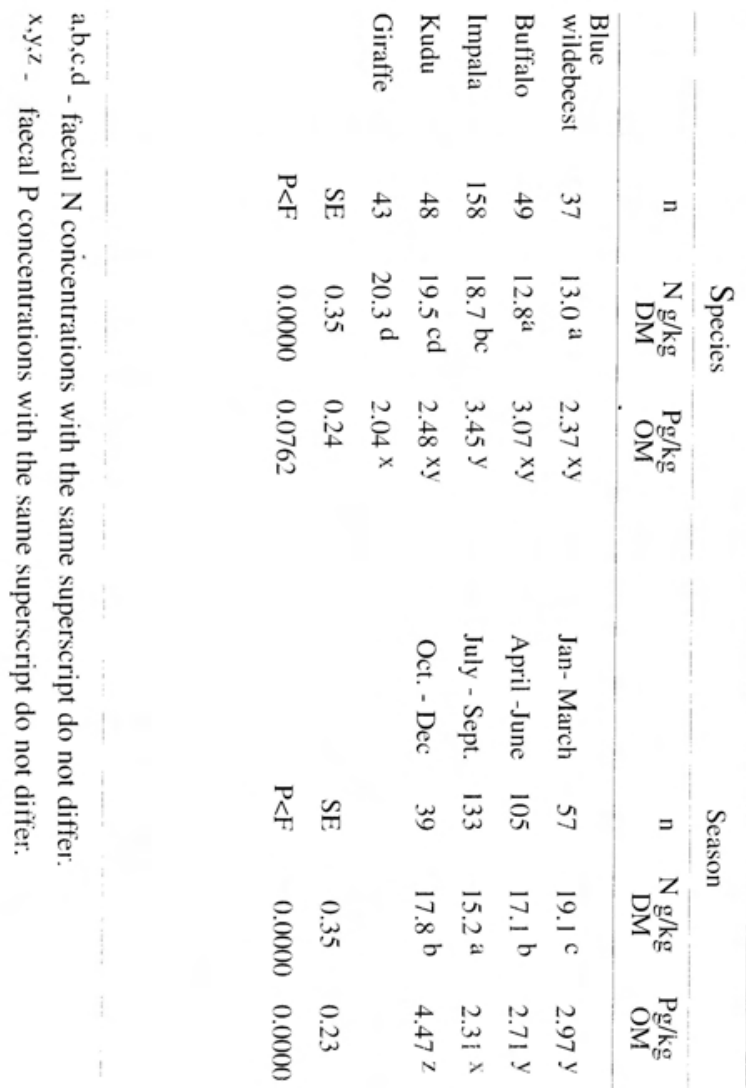

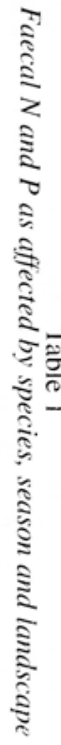

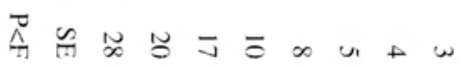

$\checkmark \mp g U_{1}=\delta \bar{\delta} \pm=$

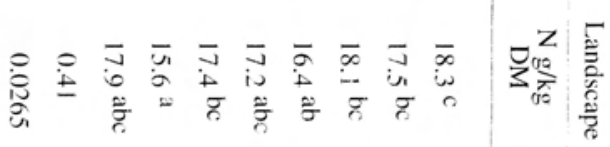

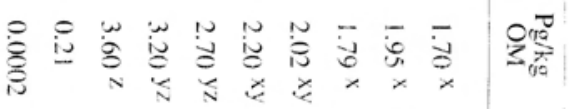


Table 2

Faecal $N$ and $P$ as affected by type of grazing, soil type in the wet season, and their interrelationship

\begin{tabular}{|c|c|c|c|c|c|c|c|c|c|c|c|c|}
\hline & \multicolumn{3}{|c|}{ Type of grazing } & \multicolumn{5}{|c|}{ Soil type per season } & \multicolumn{4}{|c|}{ Faecal P, g/kg OM } \\
\hline & $\mathrm{n}$ & $\begin{array}{c}\mathrm{Ng} / \mathrm{kg} \\
\mathrm{DM}\end{array}$ & $\begin{array}{c}\mathrm{Pg} / \mathrm{kg} \\
\mathrm{OM}\end{array}$ & & & $\mathrm{n}$ & $\begin{array}{r}\mathrm{N} \mathrm{g} / \mathrm{kg} \\
\mathrm{DM}\end{array}$ & $\begin{array}{c}\mathrm{Pg} / \mathrm{kg} \\
\mathrm{OM}\end{array}$ & & $<2.2$ & $>2.2$ & $\mathrm{P}<\mathrm{F}$ \\
\hline Grass & 86 & $13.3^{\mathrm{a}}$ & $2.90^{\mathrm{y}}$ & Granite & wet & 101 & $19.8^{\mathrm{c}}$ & $2.53^{x y}$ & $\begin{array}{l}\text { Faecal N., } \\
\mathrm{g} / \mathrm{kg} \mathrm{DM}\end{array}$ & 16.9 & 18.5 & 0.0022 \\
\hline $\begin{array}{l}\text { Grass \& } \\
\text { browse }\end{array}$ & 158 & $17.4^{\mathrm{b}}$ & $3.71^{z}$ & & dry & 153 & $16.9^{b}$ & $2.19^{\mathrm{X}}$ & \multicolumn{4}{|c|}{ Interactions } \\
\hline \multirow[t]{4}{*}{ Browse } & 91 & $22.7^{\mathrm{c}}$ & $1.97^{\mathrm{x}}$ & Basalt & wet & 15 & $18.9^{\mathrm{bc}}$ & $3.91^{z}$ & \multicolumn{4}{|c|}{ Faecal P X type of grazing 0.5591} \\
\hline & SE & 0.59 & 0.25 & & dry & 66 & $15.7^{\mathrm{a}}$ & $2.81^{\mathrm{y}}$ & \multicolumn{3}{|c|}{$X$ season } & 0.4394 \\
\hline & $\mathrm{P}<\mathrm{F}$ & 0.0000 & 0.0018 & & & $\mathrm{SE}$ & 0.41 & 0.19 & \multicolumn{3}{|c|}{$X$ soil type } & 0.4428 \\
\hline & & & & & & $\mathrm{P}<\mathrm{F}$ & 0.0000 & 0.0002 & \multicolumn{3}{|c|}{$\begin{array}{l}X \text { soil type per } \\
\text { season }\end{array}$} & 0.0265 \\
\hline
\end{tabular}

condition. Animal movements were not analysed statistically, but compared to the pre-drought census of 1991 and their relative distributions in the dry season on northern and southern granite and basalt areas.

\section{Results}

Faecal $\mathrm{N}$ and $\mathrm{P}$ concentrations were significantly affected by species, season and landscape (Table 1). For species, results correspond with their feeding habits. Blue wildebeest and buffalo, as grazers, did not differ significantly from each other. They differed from impala as mixed feeders and from kudu and giraffe as browsers. The results of kudu and giraffe also did not differ significantly. Because of the correspondence, fodder preference (type of grazing) rather than individual species was compared in subsequent analyses, i.e. grass, grass plus browse and browse.
For season, July-September showed the lowest faecal concentrations of $\mathrm{N}$ and $\mathrm{P}$ (Table 1). The highest concentrations for $\mathrm{N}$ were recorded in January-March and for $\mathrm{P}$ October-December. For both nutrients, however, the lowest concentrations occurred in the dry season and the highest in the wet season. In subsequent analyses, therefore. results of the dry season were compared with results of the wet season.

Landscapes, in terms of faecal $\mathrm{P}$ concentrations, approximately grouped according to the underlying soil type (Table 1). Landscapes 3 to 10 on granite soils did not differ significantly, but concentrations were lower than in landscapes 17 and 18 on basalt and 28 on alluvial soil. Landscape 28 , which is the Limpopo/Luvuvhu floodplains, recorded the highest $\mathrm{P}$ concentrations, but these results did not differ significantly from the basalt landscapes and were considered in subsequent analyses as "basalt". 
The highest faecal $\mathrm{N}$ concentrations were recorded in the Combretum veld of landscapes 3 and 5 and the lowest in the Phalaborwa Sandveld (landscape 8) and the Bangu Rugged Veld (landscape 20) (Table1).

With regard to type of grazing, grass showed the lowest faecal $\mathrm{N}$ concentrations and browse the highest, with grass plus browse (impala) in-between (Table 2). In contrast, faecal $\mathrm{P}$ concentrations were the highest for grass plus browse followed by grass and browse in that order.

Faecal $\mathrm{N}$ concentrations were higher on granite than on basalt soils and higher during the wet season than during the dry season (Table 2). Faecal P concentrations were also higher in the wet season but, in contrast to faecal $\mathrm{N}$, faecal $\mathrm{P}$ was higher on basalt than on granite.
Faecal $\mathrm{P}$ was significantly related to faecal $\mathrm{N}$ (Table 2) but the reciprocal (not shown) was not. Faecal $\mathrm{N}$ concentrations were lower at faecal $\mathrm{P}$ concentrations of $<2.2 \mathrm{~g} / \mathrm{kg} \mathrm{OM}$ than at concentrations of $>2.2 \mathrm{~g} / \mathrm{kg}$ OM. In the prediction of faecal $\mathrm{N}$ concentration from faecal P concentration, type of grazing, season and soil type, none of the interactions with faecal $\mathrm{P}$ was significant. When soil type per season was considered instead, the interaction was significant $(p=0.0265)$. This prediction model explained $65 \%$ of the variation in faecal $\mathrm{N}$ concentration. The interaction is best illustrated when faecal $\mathrm{P}$ concentrations are grouped in three levels, i.e. $<2.2 \mathrm{~g}, 2.2-3.0 \mathrm{~g}$ and $>3.0 \mathrm{~g} / \mathrm{kg} \mathrm{OM}$, (Fig. 2) rather than the two shown in Table 2. The results indicated a proportionally similar response of faecal $\mathrm{N}$ to faecal $\mathrm{P}$ on granite and basalt during the dry season, but a dissimilar response in the wet season. Whereas faecal $\mathrm{N}$ increased with

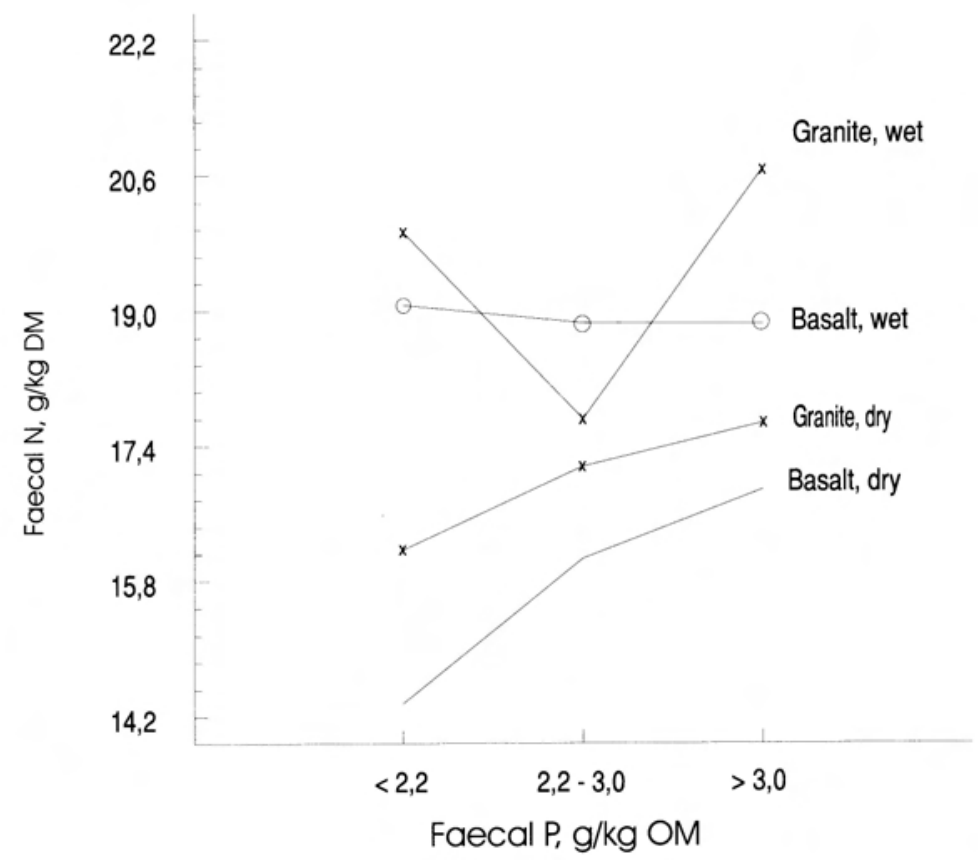

Fig. 2. Interaction of faecal $\mathrm{P}$ with soil type per season in its relation with faecal $\mathrm{N}$. 
higher faecal $\mathrm{P}$ concentrations in the dry season, it decreased non-significantly on basalt during the wet season. On granite, faecal $\mathrm{N}$ decreased between faecal $\mathrm{P}$ concentrations of $<2.2$ and $2.2-3.0 \mathrm{~g} / \mathrm{kg}$ $\mathrm{OM}$ and increased again when faecal $\mathrm{P}$ concentrations exceeded $3.0 \mathrm{~g} / \mathrm{kg} \mathrm{OM}$.

In the same prediction model, the interaction type of grazing with soil type per season was also significant $(p=0.0002)$. The results (Fig. 3) show comparatively similar responses for grazers and browsers but a different pattern for mixed feeders. With grazers and browsers, faecal $\mathrm{N}$ was lower in the dry season than the wet season, but the wet season faecal $\mathrm{N}$ concentrations were similar on granite and basalt. With mixed feeders, wet and dry season faecal $\mathrm{N}$ concentrations on basalt, were lower than wet and dry season faecal $\mathrm{N}$ concentrations on granite.
The relationship between faecal $\mathrm{P}$ and $\mathrm{N}$ for the different fodder groups was further investigated by simple linear regression. For faecal P concentrations of $<2.2 \mathrm{~g} / \mathrm{kg} \mathrm{OM}$ the relationship was negative and for faecal $P$ concentrations of $>2.2 \mathrm{~g} / \mathrm{kg}$ OM the relationship was primarily positive, although the regression was not always significant (Table 3). These results were not altered when the data of the 1994 wet season, which had more rain than the drought of 1992 and 1993, was included. The particular associations were also found by Grant (1989) with cattle in Namibia (Table 3), suggesting that they are not limited to drought or to the species investigated in the park.

The condition score of the animals was well correlated with faecal $\mathrm{N}$ concentration. For impala $r$ was $0.44(p=0.00003)$, and those with a condition score of $<2.5$ had an

Table 3

Correlations and predictions from regression of faecal $N$ concentrations when faecal $P$ concentration is respectively $<2,2$ and $>2,2 \mathrm{~g} / \mathrm{kg} O M$

\begin{tabular}{llcllll}
\hline & \multicolumn{3}{c}{$\mathrm{P}<2,2 \mathrm{~g} / \mathrm{kg} \mathrm{OM}$} & \multicolumn{3}{c}{$\mathrm{P}>2,2 \mathrm{~g} / \mathrm{kg} \mathrm{OM}$} \\
& $\mathrm{n}$ & $\mathrm{r}$ & $\mathrm{P}<\mathrm{F}$ & $\mathrm{n}$ & $\mathrm{r}$ & $\mathrm{P}<\mathrm{F}$ \\
\hline Grass & 28 & -0.66 & 0.0097 & 50 & +0.19 & 0.3718 \\
Grass and Brows & 67 & -0.65 & 0.0000 & 75 & +0.37 & 0.0011 \\
Browse & 26 & -0.65 & 0.0134 & 33 & +0.22 & 0.2175 \\
Cattle in Namibia & & & & & & \\
(Grant 1989) & 12 & -0.68 & 0.0144 & 40 & +0.44 & 0.0047 \\
& & & $\mathrm{P}, \mathrm{g} / \mathrm{kg} \mathrm{OM}$ & & & \\
\hline N, g/kg DM & 1.0 & 1.5 & 2.0 & 2.5 & 3.5 & 4.5 \\
\hline Grass & 15.5 & 13.5 & 11.6 & 12.6 & 13.1 & 13.7 \\
Grass and Brows & 20.1 & 18.3 & 16.8 & 18.2 & 18.8 & 19.5 \\
Browse & 22.0 & 18.9 & 15.8 & 20.6 & 21.0 & 21.4 \\
\hline
\end{tabular}




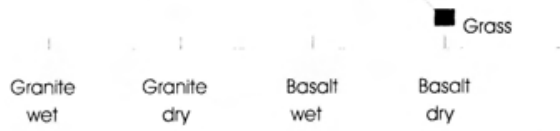

Fig. 3. Interaction of soil type per season and type of grazing in relation to faecal $\mathrm{N}$.

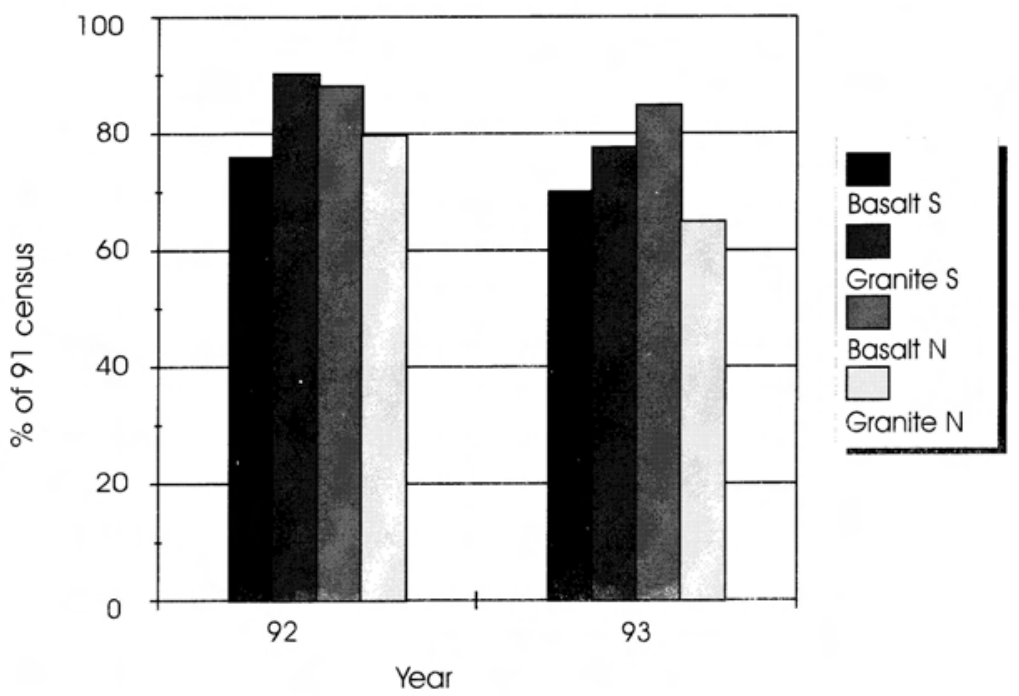

Fig. 4. Change in the impala population in basalt and granite areas in the north $(\mathrm{N})$ and south (S). Numbers of 1992-1993 expressed as a percentage of the 1991 census figure. 
average faecal $\mathrm{N}$ concentration of $16.6 \mathrm{~g} / \mathrm{kg}$ DM whereas impala with a condition score of $>2.5$ had an average faecal $\mathrm{N}$ concentration of $19.4 \mathrm{~g} / \mathrm{kg}$ DM. For grazers, the correlation was not significant $(r=0.22$ : $p=0,1027$ ), but in buffalo the 19 animals in poor condition $(<2.5)$ had an average faecal $\mathrm{N}$ concentration of $11.5 \mathrm{~g} / \mathrm{kg}$ DM which was lower $(p=0.034)$ than the faecal $\mathrm{N}$ concentration of 22 animals in good condition with a faecal $\mathrm{N}$ concentration of $13.1 \mathrm{~g} / \mathrm{kg}$ DM. The correlation for browsers was also significant $(r=0.35: p=0.0022)$. In kudu for example, the 46 animals in relatively poor condition $(<3)$ had a lower $(p=0.01)$ faecal $\mathrm{N}$ concentration of $18.1 \mathrm{~g} / \mathrm{kg}$ DM than 6 kudu with a condition score $>3$ where the faecal $\mathrm{N}$ concentration averaged $25.1 \mathrm{~g} / \mathrm{kg}$ DM.

Impala numbers decreased in the northern mopane veld on granite to $80 \%$ and $65 \%$ of the 1991 census in 1992 and 1993 respectively (Fig. 4) and in mopane veld on basalt to $88 \%$ and $85 \%$ respectively. The decrease in the Combretum veld on granite in the south was to $90 \%$ in 1992 and a further decline to $78 \%$ of the 1991 census. In the southern basalt areas of Sclerocaryal Acacia nigrescens veld, figures dropped to $76 \%$ in 1992 and to $70 \%$ in 1993 of the 1991 census.

For the browsers, kudu and giraffe, the census patterns are illustrated in Fig. 5. Kudu numbers declined sharply in the north, on granite from $106 \%$ in 1992 to $54 \%$ in 1993 of the 1991 census figures and on basalt to $74 \%$ and $59 \%$ in 1992 and 1993 respectively. In contrast, whereas the decline in the south in SclerocaryalA nigrescens veld was also particularly severe, to $62 \%$ and $51 \%$ in 1992 and 1993 respectively, there appears to have been an influx of kudu into Combretum veld (granite). The 1992 figures were up to $128 \%$ of the 1991 census. but then apparently because of the drought, dropped to $88 \%$ of the 1991 figure. Giraffe numbers actually increased dramatically in the mopane veld on basalt and only showed a moderate decline of about $10 \%$ in the northern areas (Fig. 5). An increase was also evident in the south. Giraffe numbers in Combretum veld were respectively $110 \%$ and $114 \%$ of the 1991 census figures in 1992 and 1993, and in Sclerocarya/A. nigrescens veld $85 \%$ in 1992 and $107 \%$ in 1993 of the 1991 census figure.

For grazers, blue wildebeest numbers declined in the north and southern basalt areas, but increased in the granite areas of the south (Fig. 6). In the north, the decline was more severe in the basalt areas. $76 \%$ in 1992 and $46 \%$ in 1993 respectively, than in the granite areas, respectively $80 \%$ in 1992 and $65 \%$ in 1993. Buffalo numbers dropped dramatically in the mopane veld in 1993 , from $119 \%$ in the basalt areas and $100 \%$ in the granite areas in 1992, to $64 \%$ and $38 \%$ in 1993 respectively (Fig. 6). In the south. numbers also decreased in the basalt areas but there appears to have been an influx of buffalo into the Combretum veld on granite, similar to the influx shown for kudu (Fig. 5) and blue wildebeest. Buffalo numbers here increased to respectively $311 \%$ and $144 \%$ of the 1991 census figure.

\section{Discussion}

\section{Method justification}

The method of faecal analysis proved useful to monitor changes in fodder quality. Faecal $\mathrm{N}$ and $\mathrm{P}$ concentrations were effective in distinguishing between ruminant species, in particular as they pertain to feeding habits, i.e. grazers, browsers and selective feeders (impala) (Tables 1 and 2). They could also categorise seasons and landscapes, showing specific differences between the wet and dry seasons and between landscapes on granite 


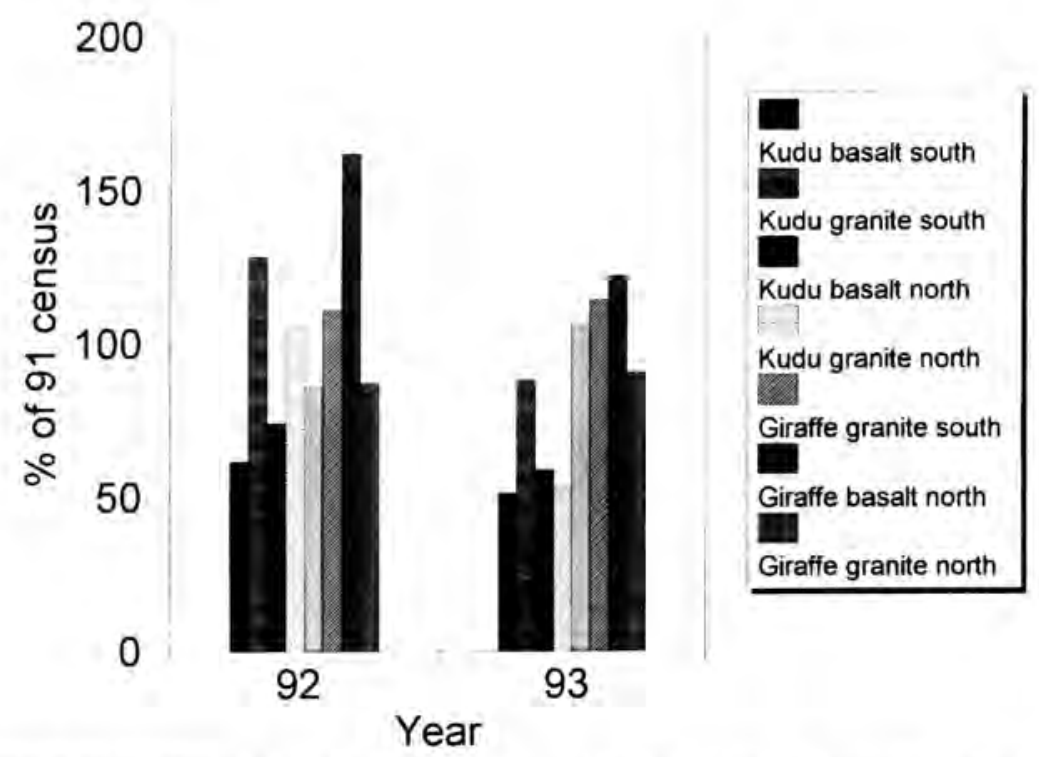

Fig. 5. Change in the population of kudu and giraffe (browsers) in the basaltic and granitic areas in the north (N) and south (S). Numbers of 1992-1993 expressed as a percentage of the 1991 census figure.

vs. basalt soils. What is of concern during seasonal or long-term droughts, is that a proposed method should be able to indicate critical nutrient levels. Grant (1989) indicated from their work on cattle that the level for $\mathrm{N}$ was $10.5 \mathrm{gN} / \mathrm{kg} \mathrm{DM}$ and for $\mathrm{P}$ about $2 \mathrm{gP} / \mathrm{kg}$ OM. Other workers (Wofford et al. 1985) found a somewhat higher $\mathrm{N}$ level of $12 \mathrm{~g} / \mathrm{kg} \mathrm{DM}$.

The faecal $\mathrm{N}$ concentration of about $11 \mathrm{~g} / \mathrm{kg}$ DM proved useful for grazers in the park as it coincides with the minimum $\mathrm{N}$ concentration in grass necessary to maintain rumen fermentation, i.e. about $11-12 \mathrm{gN} / \mathrm{kg}$ DM (Minson 1967: Meissner \& Pieterse unpubl.). In this regard it was evident that the condition of buffalo deteriorated rapidly when their faecal $\mathrm{N}$ concentration fell below $11.5 \mathrm{~g} / \mathrm{kg}$ DM. For short grass feeders, selective feeders and browsers this critical $\mathrm{N}$ level would seldom occur and, because faecal $\mathrm{N}$ is also positively related to fodder digestibility (Moir 1960; Holecheck et al. 1982), the influence of drought for them is mainly lack of food rather than quality. For buffalo, a severe decrease in digestibility further contributes to their predicament, even before grass becomes limiting.

As with the study of Grant (1989) on cattle, $2 \mathrm{gP} / \mathrm{kgOM}$ was a distinguishing level in this investigation, irrespective of species. Regression analyses showed the highest correlations below vs, above $2.2 \mathrm{~g}$ faecal $\mathrm{P} / \mathrm{kg}$ OM (Table 3 ), although the relationships are modified by soil type per season interaction (Fig. 2), Below $2.2 \mathrm{gP} / \mathrm{kg} \mathrm{OM}, \mathrm{N}$ concentration in the faeces increased with a decrease in faecal $\mathrm{P}$ concentration, even though fodder $\mathrm{N}$ concentration would be declining since this will primarily occur in the dry season. Because of the intensity and duration of the drought, protein in the 


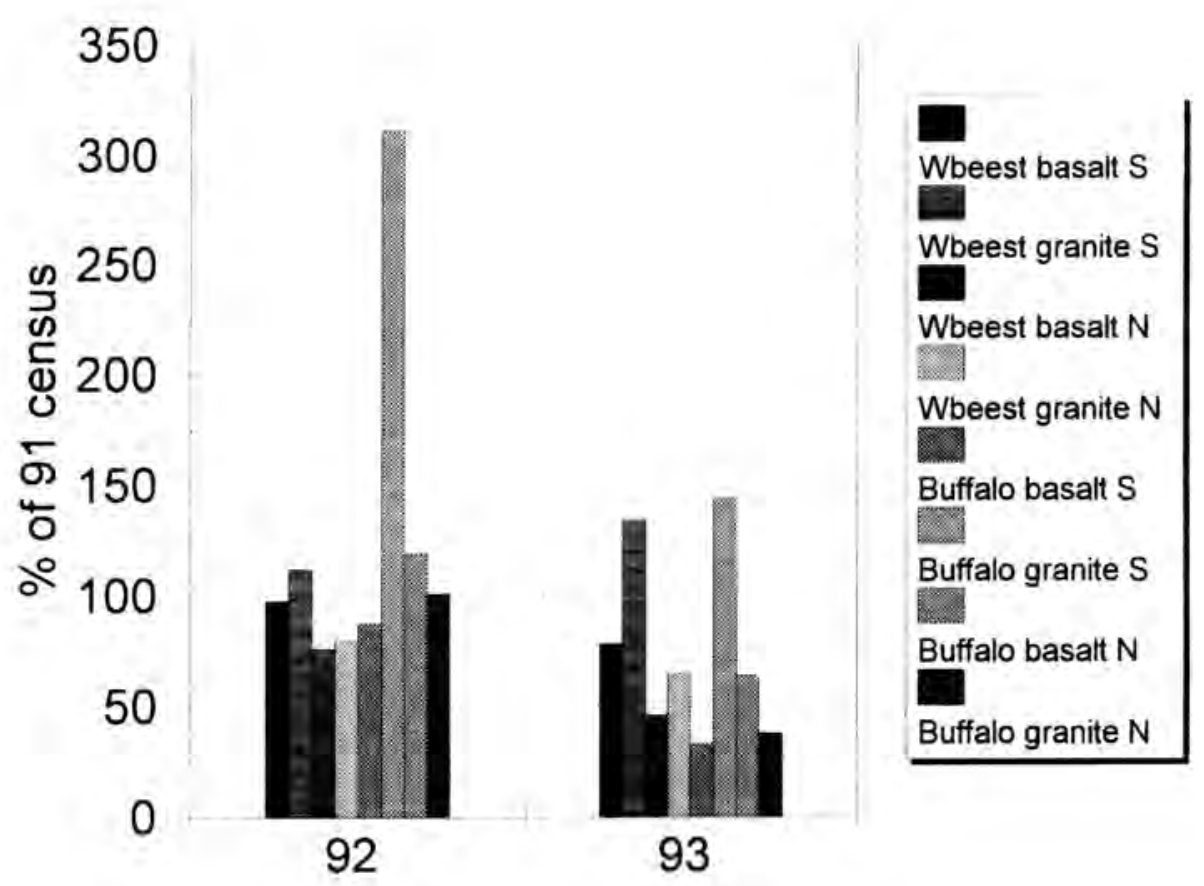

Fig. 6. Change in the population of blue wildebeest and buffalo (grazers) in the basaltic and granitic areas in the north (N) and south (S). Numbers of 1992-1993 expressed as a percentage of the J991 census figure.

animal body will be catabolised resulting in an increase in urinary $\mathrm{N}$ from higher amount of urea excreted. Some of the urea may be secreted through the intestinal wall back into the gut lumen (Thornton et al. 1970; Varaday et al. 1979) where breakdown of protein occurs (Webster 1983), which would account for the higher faecal $\mathrm{N}$ concentration. If at this stage $\mathrm{P}$ is the first limiting nutrient, which apparently is the case below $2 \mathrm{~g}$ faecal $\mathrm{P} / \mathrm{kg} \mathrm{OM}$, the excretion of $\mathrm{N}$ will be enhanced.

The interaction between $\mathrm{N}$ and $\mathrm{P}$ discussed above, illustrates the importance of considering both faecal and $\mathrm{P}$ concentrations when interpreting results. This has also been recommended by Moir (1966) and Grant (1989). It must also be borne in mind that faecal $\mathrm{N}$ and $\mathrm{P}$ do not only reflect fodder levels of those nutrients, but also $\mathrm{N}$ and $\mathrm{P}$ of endogenous origin that are determined by imbalances as implied above, and efficiency of utilisation. The contribution of endogenous $\mathrm{P}$ to faecal $\mathrm{P}$ in particular, cannot be established without prior calibration. Therefore, it is uncertain if the low faecal $P$ concentrations of browsers, particularly giraffe (Tables 1 and 2), resulted because of low $\mathrm{P}$ in browse, or because browse $\mathrm{P}$ is utilised more efficiently. This should be 
further investigated because signs of pica in the south were observed for giraffe.

\section{Type of grazing and soil in relation to ani- mal condition and movement}

Faecal $\mathrm{N}$ concentrations were lowest for grass and highest for browse according to expectation because, whereas grass loses its nutritive value when maturing or becoming dormant, browse maintains its nutritive value. Faecal $\mathrm{P}$ concentrations were highest for grass plus browse (Table 2) followed by grass and then browse. The highest faecal $\mathrm{P}$ may be the result of the particular feeding behaviour of impala. Being selective feeders, they manage to obtain a nutritious diet almost throughout the year (Meissner et al. 1992; Pietersen et al. 1993) provided succulent shrub, forb and herb leaves and shoots are available. If there is a ranking order in $\mathrm{P}$ content from low for high browse (giraffe) to intermediate (kudu) to high for low browse (Table 1), the food stratum of the impala appears to be particularly favourable, because it benefits from a relative high grass $\mathrm{P}$ content in the wet season and high P levels in the lower browse layers. Nevertheless, because of overgrazing resulting in soil depletion and bush encroachment, certain landscapes, particularly those on granite soils (Table 2), may become limiting in $\mathrm{P}$ even for impala. For example, faecal $\mathrm{P}$ concentrations were below $2 \mathrm{~g} / \mathrm{kg} \mathrm{OM}$ in the Sabie thickets and the Combretum woodland (both granite areas) and values on occasion dropped to below 1g/kg OM during March - April 1992. These faecal $\mathrm{P}$ values could have contributed to a delay in oestrus with a consequently later breeding season resulting in the late lambing season as impala lambs were born later than usual in the Sabie thickets (Grant et al. unpublished). It could also have been associated with nutritional stress as the seasonal pattern of faecal $\mathrm{P}$ and
N (Fig. 7) coincided with cortisol levels measured by Knox (1993 pers. comm.) in this area. In general quality of diet as reflected in faecal $\mathrm{N}$ concentrations, was not limiting to impala, even though basalt areas seemed less favourable than granite areas (Fig. 2). Total food, however proved limiting in 1992 (Meissner et al. 1992). This was reflected in a condition score of $<2.5$ in the south.

On grass, faecal $\mathrm{N}$ concentrations dropped below $11 \mathrm{~g} / \mathrm{kg} \mathrm{DM}$ in the dry season on basalt areas (Fig. 3). Whereas low $\mathrm{N}$ levels were also recorded on granite landscapes, the incidence there-of was less common. In granite areas, very low faecal $P$ concentrations occurred from May to August and even longer. For example, in blue wildebeest faecal $\mathrm{P}$ concentrations declined to below $2 \mathrm{~g} / \mathrm{kg} \mathrm{OM}$ in the Combretum veld from March to September, whereas they stayed well above $2 \mathrm{~g} / \mathrm{kg} \mathrm{OM}$ in basalt areas. The higher $\mathrm{N}$ concentrations of granite areas, which would also indicate higher digestibility of the grass apparently affected movement of buffalo and blue wildebeest towards the southern Combretum veld (Fig. 6), even though blue wildebeest should have been less affected by poor grass quality, being short grass feeders. Their relatively good condition in all landscapes supports this contention.

Overall, buffalo being tall grass feeders, could not cope with the adverse conditions of the 1992-1993 drought. Their condition was poor and their population declined drastically. Calving percentage was also very poor, $6.1 \%$ in 1992 and $4.2 \%$ in 1993 (Whyte \& Wood 1994). Whereas lack of food was probably the primary contributor, low $\mathrm{N}$ and $\mathrm{P}$ levels were clearly also contributing to the decline in buffalo numbers and their low calving rate. 


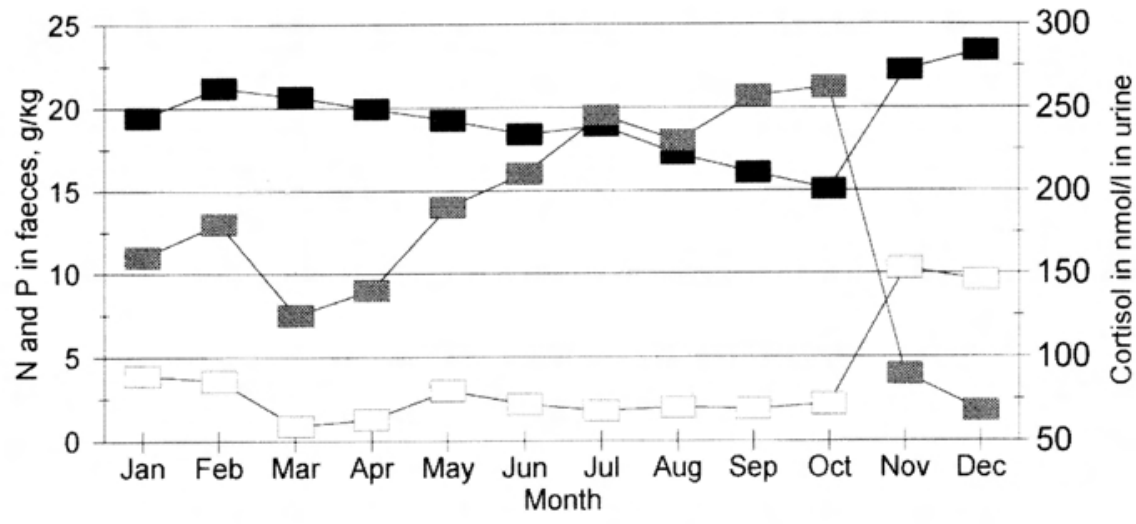

Nitrogen Cortisol $\square$ Phosphorus

Fig. 7. Monthly variation in faecal $\mathrm{N}$ and $\mathrm{P}$ in relation to urinary cortisol levels in the Sabie Thickets.

Browsers should not be affected by a short term or seasonal drought as long as shrubs and trees are still available. Faecal $\mathrm{N}$ concentrations, reflecting also digestibility as discussed before, stayed well above critical values (Table 2 and Fig. 3), also for basalt landscapes in the dry season. Faecal $\mathrm{P}$ concentrations became critically low, particularly for giraffe, but as implied previously, it is not known whether these low levels reflect good $\mathrm{P}$ utilisation rather than low browse P levels. The low P levels were mainly recorded in the Sabie thickets and Combretum woodland on granite from March to July 1992, and because this observation also applied for impala, it would appear that soil fertility in the Sabie thickets has declined which could be critical during long-term droughts as experienced during 1992-1993.

The availability of browse to kudu would have become limiting during the study period because they also compete with other browsers. Giraffe, in contrast, can browse higher. Therefore, whereas kudu did show a decline in condition and suffered a substantial drop in total numbers (Fig. 5), giraffe condition was generally good and their census figure actually increased to $108 \%$ of the 1991 figure. Apart from total availability of food, especially in the north, the presence of deterrents in the foliage (like tannins) might have been a contributing factor in explaining the influx of kudu into the southern Combretum granites. It is postulated that their browse layer would 
have contained or gained more tannins / phenols than that of giraffe, because giraffe tend to prefer Acacia spp which are generally low in condensed tannins (OwenSmith 1993). Combretum spp. on moderately nutrient-poor soils such as granite on the other hand, do contain relatively high proportions of possibly hydrolysable tannins but are mostly palatable (Owen-Smith 1993).

The deterrent compounds, apart from being unpalatable, decrease protein digestibility, resulting from the present perspective in too high $\mathrm{N}$ in the faecal analysis and therefore an overestimation of fodder digestibility and available nitrogen. This problem requires calibration and an investigation into its association with landscape.

\section{Conclusions and Implications}

The 1992-1993 drought was probably nutritionally one of the worst that herbivores in the park would experience. From a scientific point of view on the other hand, valuable information could be obtained giving insight into the resilience and recovery of the ecosystems, and from the present perspective, the opportunity to test the value of faecal $\mathrm{N}$ and $\mathrm{P}$ analyses as a monitoring tool, in addition to studying the relation between nutritive value of the veld and migratory movements of the most prominent ruminants. The objective with faecal analysis was met because the method was effective in distinguishing between species, feeding habits, landscapes, soil types and seasons. Because critical faecal $\mathrm{N}$ and $\mathrm{P}$ concentrations in relation to animal condition could also be defined, routine monitoring would be useful to aid management decisions on culling or shifting of animals through for example waterpoint closure (Trollope et al. 1989). The method could also indicate that the influx of some species into the (granite) Combretum veld of the south of the park was most probably nutritionally related.

From the results it was evident that buffalo as bulk grazers would suffer most in longterm droughts because of a relatively rapid decline in food quality preceding the decline in available fodder. Therefore, the buffalo population should, in conjunction with anthrax, tuberculosis and predation, be reasonably well controlled by climatic cycles. This is illustrated by the relationship between the census figures and rainfall since 1980 (Whyte \& Wood 1994). Short-grass feeders such as blue wildebeest and a browser such as kudu that compete with other browsers, would only experience a decline in numbers if the available food becomes limiting. Giraffe, because of essentially no competition, should only rarely experience a limitation in food availability, and should not experience a limitation in food quality, apart from maybe $P$ in granite areas. Giraffe numbers could even increase where bush encroachment is a feature of veld deterioration. Impala numbers are most probably not controlled by nutritional means. Being highly selective, they will normally be able to obtain a diet adequate in quality and quantity to survive even under adverse conditions. They are also prolific breeders and residential and therefore their numbers should be actively controlled in sensitive areas. Such intervention should also be favourable to endangered bulk grazing ruminants.

The comments above imply that the veld in the park should be managed to maintain bulk grazers as suggested by Trollope et al. (1989). The carrying capacity of veld for the different herbivores can at best, however, be a dynamic equilibrium and estimates thereof should be obtained through development of a multi-factor model. 


\section{Acknowledgements}

Infrastructure was provided by Management at Skukuza. Financial support came from the University of Pretoria and the FRD. H. C. Biggs is thanked for statistical assistance, P. Viljoen for making available the detailed annual census figures, J. Wessels for doing the analyses and the game rangers for helping with the collection of samples.

\section{References}

AOAC. 1975. Official methods of analysis. $12 \mathrm{ed}$ Arlington, Virginia, USA: Association of Official Analytical Chemists.

AOAC. 1984 Official methods of analysis. 14 ed. Arlington, Virginia, USA: Association of Official Analytical Chemists.

Belonje, P.C. 1980. The use of faecal analyses to estimate the phosphorus intake by grazing sheep. 1 . The use of pooled instead of individual samples. Onderstepoort Journal of Veterinary Research 47: 163-167.

GertenbACH, W.P.D. 1983. Landscapes of the Kruger National Park. Koedoe 26: 9-121.

Grant, C.C. 1989. Development of a system classifying and monitoring the availability of minerals to cattle in the ranching areas of SWA/Namibia. DVSc thesis, University of Pretoria, Pretoria.

Holecheck, J.L., M. Vavra and R.D. PIEPER. 1982. Methods for determining the nutritive value of range ruminant diets. Journal of Animal Science 54: 363-376.

LANCASTER, R.J. 1949. The measurement of feed intake of grazing cattle and sheep. 1. A method of calculating the digestibility of pasture based on the nitrogen content of faeces derived from the pasture. New Zealand Journal of Science and Technology 31: 31-33.

Meissner, H.H., E. Pieterse and J.H.J. Potgieter. 1992. Food selection and intake of male impala
(Aepyceros melampus) on two habitats. In: Proceedings 3rd International Wildlife Ranching Symposium. Pretoria: 27-30 Oct. 1992

Minson, D.J. 1967. The voluntary intake and digestibility, in sheep, of chopped and pelleted Digitaria decumbens (pangola grass) following a late application of fertilizer nitrogen. British Journal Nutrition 21: 587-597.

Molr, K.W. 1960. Nutrition of grazing cattle. 1. Estimation of protein in pasture selected by grazing cattle. Queensland Journal of Agricultural Science 17: 361-371.

MoIR, K.W. 1966. Diagnosis of phosphorus deficiency in grazing cattle. Queensland Journal of Agricultural and Animal Science 23: 97-100.

OWEN-Smith, N. 1993. Woody plants, browsers and tannins in southern African savannas. South African Journal of Science 89: 505-510.

Pietersen, L.M., H.H. Meissner, E.W. Pietersen. 1993. Food selection and intake by male impalas in the Timbavati area. South African Journal of Wildlife Research 3: 6-11.

Thornton, R.F., P.R. BIRD, M. SOMERs and R.J. MoIR. 1970. Urea excretion in ruminants. III. The role of the hind-gut (caecum and colon). Australian Journal of Agricultural Research 21: 345-354.

Trollope, W.S.W., A.L.F. Potgieter and N. Zambatis. 1989. Assessing veld condition in the Kruger Park using key grass species. Koedoe 32: 67-93.

Viljoen P.C., M.A. Rochat and C.A. Wood. 1993. Ecological survey in the Kruger National Park. 1/94. Internal Report.

Varaday, J., K. Boda, K.T. Tasenov and J. Fejes. 1979. Nitrogen excretion into the digestive tract of sheep. Annales de Recherces Vétérinaires 10: 448450.

Wadsworth, J.C., R.W. McClean, D.B. COATS AND W.H. WinTER. 1990. Phosphorus and beef production in northern Australia. 5. Animal phosphorus status and diagnosis. Tropical Grassland 24: 185196.

Webster, A.J.F. 1983. Nutrition and the thermal environment. In: RoOK, J.A.F. AND P.C. ThOMAS (eds.) Nutritional Physiology of Farm Animals. New York: Longman Inc. 